\title{
A Comparative Study of Job Satisfaction in Government and Private Employees
}

\author{
Ajay Chauhan*, Dr. Pravin M. Solanki**
}

\section{ABSTRACT:}

The main objective of the present study is to examine the job satisfaction among government and private employees. A sample of 60 male and female employees was drawn randomly drawn from the population. The Generic Job Satisfaction Scale: Scale Development and Its Correlates, developed by Scott Macdonald and Peter Maclntyre (1997) was used for data collection. Data was collected by face to face interview method from the target population from different originations of Anand district. Mean, standard deviation and t-test were calculated for the analysis of data. Results indicate that there is no significant difference among government and private employees in job satisfaction.

Keywords: Job Satisfaction, Private and Government Employees

\section{INTRODUCTION}

Job satisfaction is a set of favorable or unfavorable feelings with which employees view their work. It is a worker's sense of achievement and success and is generally perceived to be directly linked to productivity as well as to personal wellbeing. The happier people are within their job, the more satisfied they are said to be. Job satisfaction implies doing a job one enjoys, doing it well, and being suitably rewarded for one's efforts. Job satisfaction can be influenced by a variety of factors, e.g., the quality of one's relationship with their supervisor, the quality of the physical environment in which they work, degree of fulfillment in their work, etc.. Job satisfaction further implies enthusiasm and happiness with one's work Job satisfaction; describes how satisfied an individual is with his or her job. Job satisfaction is not the same as motivation, although it is closely linked, but satisfaction includes the management style and culture, employee involvement, empowerment and autonomous work groups. Job satisfaction is a very important attribute which is frequently measured by organizations. The most common way of measurement is the use of rating scales where employees report their reactions to their jobs.

*MA, Clinical Psychology, Dept. of Psychology, Sardar Patel University, Vallabh Vidhyanagar, Guj. Ind

**PhD, Dept. of Psychology, M. K. Bhavnagar University, Bhavnagar, Guj. Ind 
Questions related to rate of pay, work responsibilities, variety of tasks, promotional opportunities the work itself and co-workers. For the organization, job satisfaction of its workers means a work force that is motivated and committed to high quality performance. Increased productivity-the quantity and quality of output per hour worked - seems to be a byproduct of job satisfaction. Employee satisfaction surveys provide the information needed to improve levels of productivity, job satisfaction, and loyalty. Organizations can identify the root causes of job issues and create solutions for improvements with an accurate perspective of employee views discover what motivates people, what drives loyalty, and what genuinely makes and keeps your employees happy. Satisfaction levels increase when an employee knows that their issues are being addressed. There is a direct link between employee, job satisfaction and financial results. The more satisfied your employees are the more motivated and committed they will be towards the organization's success. In this Research paper we have tried to make a comparison of Job satisfaction between Private and Govt. sector and tried to find out the basic reasons of dissatisfaction in job.

\section{REVIEW OF LITERATURE}

The major objective of this Paper is to examine the nature and causes of job satisfaction. This was pursued through a literature review of the more popular theories and models related to job satisfaction. Included in the review are summaries of Maslow's and Alderfer's need hierarchy theories, achievement motivation theory, Herzberg's motivation-hygiene theory, expectancy theory, job characteristics theories, discrepancy theory, equity theory, and studies relating to the clustering of facet satisfactions. Job satisfaction is simply defined as doing a job one enjoys, doing it well, and being suitably rewarded for one's efforts. In other words, it is an effective response to a job that consequences from the comparison of perceived outcomes with those that are desired shortly, job satisfaction describes the feelings, attitudes or preferences of individuals regarding work (Chen, 2008). Furthermore, it is the degree to which employees enjoy their jobs (McCloskey and McCain, 1987). And also, it is possible to see a number of theories developed to understand its nature in literature. Vroom (1964), need/value fulfillment theory, states that there is negative relationship between individual needs and the extent to which the job supplies these needs.

\section{OBJECTIVES}

1. To study Job Satisfaction in Government and Private Employees.

2. To study Job Satisfaction in Government male and female employees.

3. To study Job Satisfaction in Private male and female employees.

4. To study Job Satisfaction in Government and Private male Employees.

5. To study Job Satisfaction in Government and Private female Employees.

\section{HYPOTHESIS}

1. There is no significant different between Government and Private Employees.

2. There is no significant different between Government male and female employees.

3. There is no significant different between Private male and female employees.

4. There is no significant different between Government and Private male Employees.

5. There is no significant different between Government and Private female Employees. 


\section{METHODOLOGY}

\section{Population}

The population selected for this particular study is employees of government $\&$ private sector of different service sectors in Anand District (Gujarat State).

\section{Sampling}

The sampling population of this research includes 60 employees of government \& private sector of different service sectors. This research followed the random sampling method representative population. The population belongs to an age group of 30-50.

\section{Tools of data collection}

The Generic Job Satisfaction Scale: Scale Development and Its Correlates, developed by Scott Macdonald and Peter Maclntyre (1997)

\section{ANALYSIS AND RESULTS}

Table no. 1, Job Satisfaction in Government and Private Employees.

\begin{tabular}{|l|l|l|l|l|l|l|}
\hline \multicolumn{1}{|c|}{ Groups } & \multicolumn{1}{c|}{$\mathbf{N}$} & \multicolumn{1}{c|}{ Mean } & \multicolumn{1}{c|}{ SD } & \multicolumn{1}{|c|}{ SEM } & \multicolumn{1}{c|}{ t } & \multicolumn{1}{c|}{ Level } \\
\hline Government & 30 & 5.93 & 1.82 & 0.33 & 0.1840 & NG \\
\cline { 1 - 2 } Private & 30 & 6.03 & 2.36 & 0.43 & & 0.01 \\
\hline
\end{tabular}

The above table no. 1 shows the mean difference between two groups (government and private) in terms of job satisfaction. The mean for the government employees is 5.93 and SD 1.82, as well as the mean of private employees is 6.03 and SD 2.36. The obtained " $t^{\text {ee }}$ is 0.1840 , which is no significant at 0.01 levels. Hence it is concluded that there is no significant difference between government and private employees in terms of their job Satisfaction.

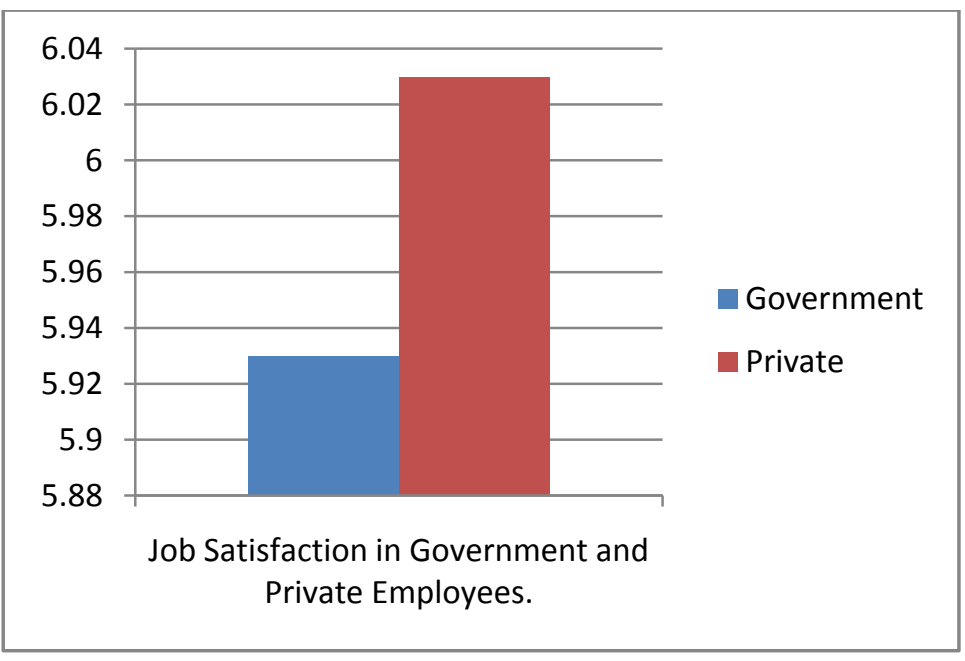


Table no. 2 Job Satisfaction in Government male and female Employees.

\begin{tabular}{|l|l|l|l|l|l|l|}
\hline \multicolumn{1}{|c|}{ Groups } & \multicolumn{1}{c|}{$\mathbf{N}$} & \multicolumn{1}{c|}{ Mean } & \multicolumn{1}{c|}{ SD } & \multicolumn{1}{c|}{ SEM } & \multicolumn{1}{c|}{ Level } \\
\hline Male & 15 & 5.80 & 1.66 & 0.43 & 0.3958 & NS \\
\cline { 1 - 4 } & 15 & 6.07 & 2.02 & 0.52 & & 0.01 \\
\hline
\end{tabular}

The above table no. 2 shows the mean difference between two groups (male and female) in terms of job satisfaction. The mean for the government male employees is 5.80 and SD 1.66, as well as the mean of female employees is 6.07 and SD 2.02. The obtained "tee is 0.3958 , which is no significant at 0.01 levels. Hence it is concluded that there is no significant difference between government male and female employees in terms of their job Satisfaction.

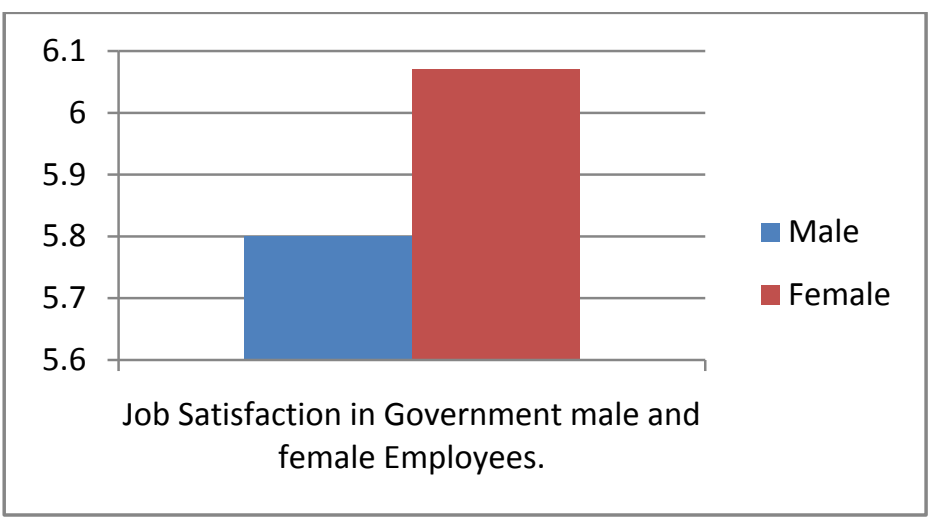

Table no.3 Job Satisfaction in Private male and female Employees.

\begin{tabular}{|l|l|l|l|l|l|l|}
\hline \multicolumn{1}{|c|}{ Groups } & \multicolumn{1}{c|}{$\mathbf{N}$} & \multicolumn{1}{c|}{ Mean } & \multicolumn{1}{c|}{ SD } & \multicolumn{1}{|c|}{ SEM } & \multicolumn{1}{|c|}{ Level } \\
\hline Male & 15 & 5.47 & 2.33 & 0.60 & \multirow{2}{*}{1.3351} & NS \\
\cline { 1 - 6 } Female & 15 & 6.60 & 2.32 & 0.60 & & 0.01 \\
\hline
\end{tabular}

The above table no. 3 shows the mean difference between two groups (male and female) in terms of job satisfaction. The mean for the private male employees is 5.47 and SD 2.33, as well as the mean of female employees is 6.60 and SD 2.32. The obtained "tee is 1.3351, which is no significant at 0.01 levels. Hence it is concluded that there is no significant difference between private male and female employees in terms of their job Satisfaction.

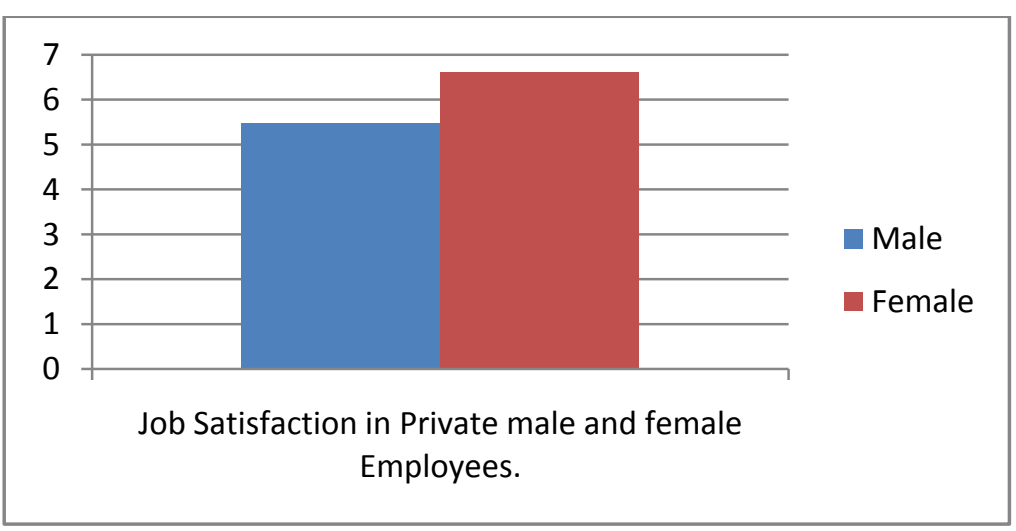


Table no.4, Job Satisfaction in Government and Private male Employees.

\begin{tabular}{|l|l|l|l|l|l|l|}
\hline \multicolumn{1}{|c|}{ Groups } & \multicolumn{1}{|c|}{$\mathbf{N}$} & \multicolumn{1}{|c|}{ Mean } & \multicolumn{1}{|c|}{ SD } & \multicolumn{1}{|c|}{ SEM } & \multicolumn{1}{c|}{ t } & \multicolumn{1}{c|}{ Level } \\
\hline $\begin{array}{l}\text { Government } \\
\text { (M) }\end{array}$ & 15 & 5.80 & 1.66 & 0.43 & 0.4521 & $\begin{array}{l}\text { NS } \\
0.01\end{array}$ \\
\hline Private (M) & 15 & 5.47 & 2.33 & 0.60 & & \\
\hline
\end{tabular}

The above table no. 4 shows the mean difference between two groups (male) in terms of job satisfaction. The mean for the government male employees is 5.80 and SD 1.66, as well as the mean of private male employees is 5.47 and SD 2.33. The obtained "ee is 0.4521 , which is no significant at 0.01 levels. Hence it is concluded that there is no significant difference between government and private male's employees in terms of their job Satisfaction.

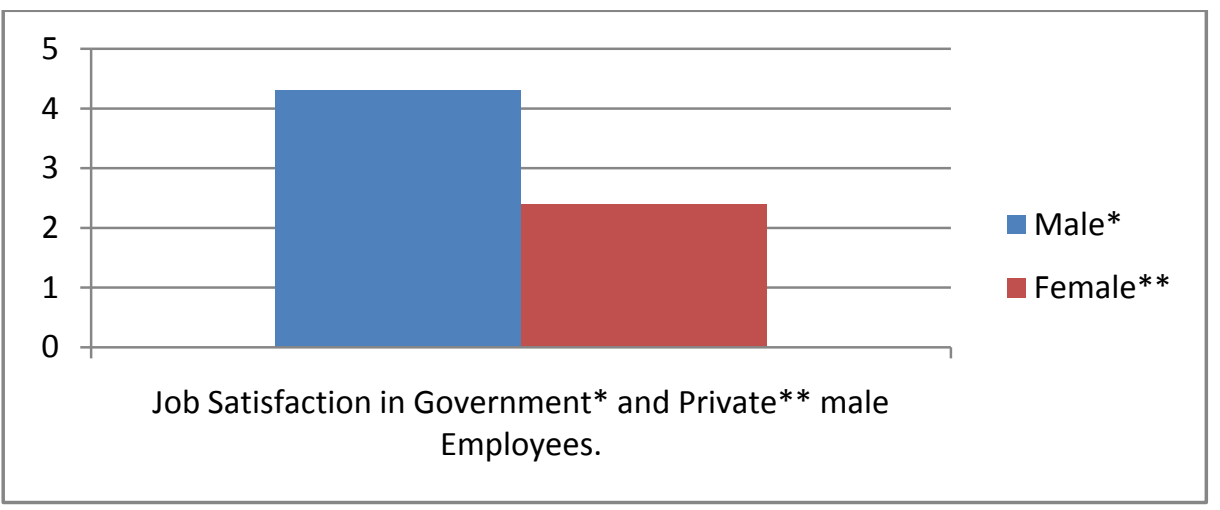

Table no. 5, Job Satisfaction in Government and Private female Employees.

\begin{tabular}{|l|l|l|l|l|l|l|}
\hline \multicolumn{1}{|c|}{ Groups } & \multicolumn{1}{c|}{$\mathbf{N}$} & \multicolumn{1}{c|}{ Mean } & \multicolumn{1}{c|}{ SD } & \multicolumn{1}{c|}{ SEM } & \multicolumn{1}{c|}{ t } & \multicolumn{1}{c|}{ Level } \\
\cline { 1 - 4 } $\begin{array}{l}\text { Government } \\
\text { (F) }\end{array}$ & 15 & 6.07 & 2.02 & 0.52 & 0.6713 & $\begin{array}{l}\text { NS } \\
0.01\end{array}$ \\
\cline { 1 - 5 } Private (F) & 15 & 6.60 & 2.32 & 0.60 & & \\
\hline
\end{tabular}

The above table no. 5 shows the mean difference between two groups (female) in terms of job satisfaction. The mean for the government female employees is 6.07 and SD 2.02, as well as the mean of private female employees is 6.60 and SD 2.32. The obtained "tee is 0.6713 , which is no significant at 0.01 levels. Hence it is concluded that there is no significant difference between government and private female's employees in terms of their job Satisfaction.

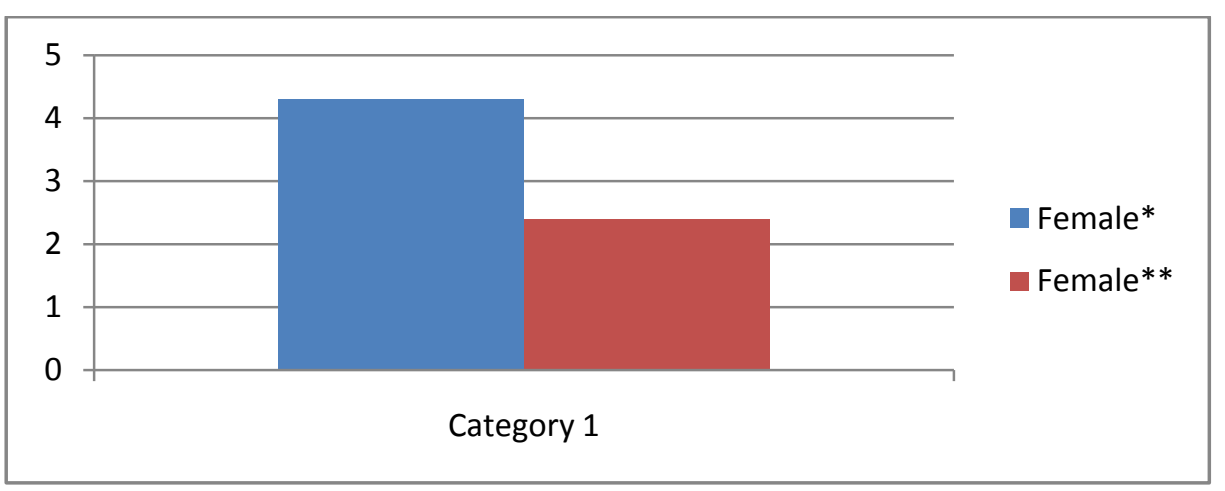




\section{CONCLUSION}

1. No significant different between Government and Private Employees.

2. No significant different between Government male and female employees.

3. No significant different between Private male and female employees.

4. No significant different between Government and Private male Employees.

5. No significant different between Government and Private female Employees.

So, we accept the entire null hypothesis.

\section{REFERENCE}

1. Brief, cited in Weiss, H. M. Deconstructing job satisfaction: separating evaluations, beliefs and affective experiences. Human Resource Management Review,2002,12, 173194

2. Fried Y, Ferris GR. The validity of the Job Characteristics Model: A review and metaanalysis. Personnel Psychology,1987,40,287-322

3. Rafaeli A, Sutton RI. The expression of emotion in organizational life. Research in Organizational Behavior,1989,11, 1-42

4. Abraham R. The impact of emotional dissonance on organizational commitment and intention to turnover. Journal of PsycholoGy,1999,133, 441-455

5. Morris JA, Feldman DC. Managing emotions in the workplace. Journal of Managerial Issues , 1997, 9, 257-274

6. Organ DW, Ryan KA Meta-analytic review of attitudinal and dispositional predictors of organizational citizenship behavior. Personnel Psychology,1995, 48, 775-802

7. Scott Macdonald and Peter Maclntyre (1997), The Generic Job Satisfaction Scale: Scale Development and Its Correlates, The Haworth Press Inc

8. Shobhna Gupta J, Hartesh Pannu K (2013), A Comparative Study of Job Satisfaction in Public and Private Sector, Indian Journal of Arts, V-1, N-1, 2013 